\title{
Albanon
}

Revistë kulturore

\section{Banja e Ad Quintum (milium), Bradashesh (Elbasan)}

Mario de Matteis dhe Jozefina Palushaj

Ndërtimi: Gjysma e dytë e shekullit II pas Krishtit; teknikë ndërtimi: opus incertum.

Braktisja e strukturës termale, jo aq shumë për shkak të zhvillimit qytetar të Skampës fqinje, por pothuajse me siguri për shkak të përdorimit të reduktuar të stacionit stacionar (mutatio) është vërtetuar nga historianët dhe studiuesit, në fillimin e shekullit VI pas Krishtit.

Kompleksi arkitektonik i përbërë nga spas dhe nymphaeum (exedra) u zbulua në vitin 1968 gjatë një fushate gërmimi arkeologjik nga arkeologu i

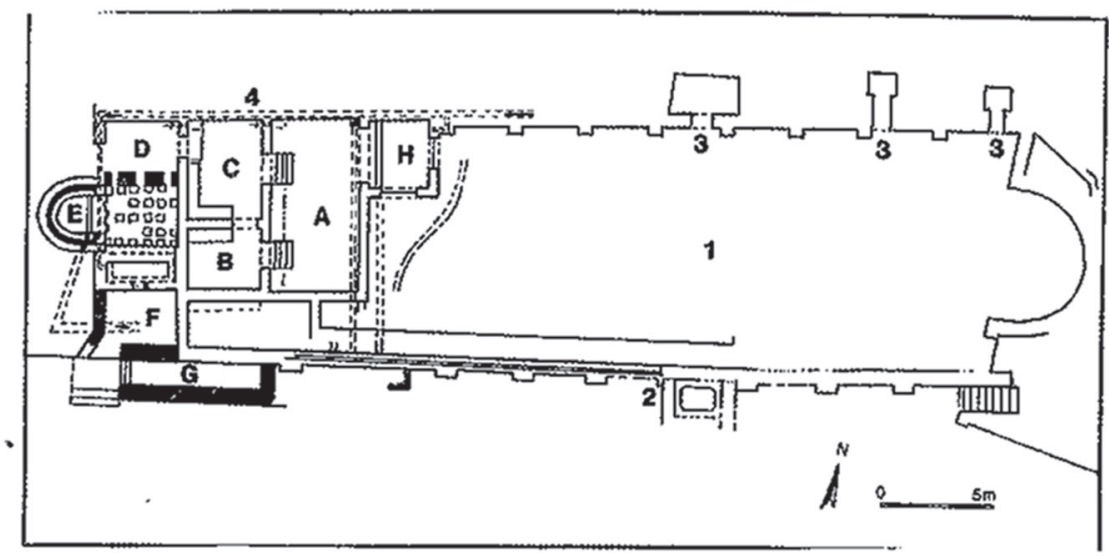

Planimetria dhe relievi i termave romake (nga Koch, 1989:154; Përpunimi në: de Matteis, 2011: 82): 1. Tarracë e hapur; 2. Lotim për kafshët; 3. Rezervuare të mbledhjes së ujit të burimit; 4. Dhomë e larjes: $A=$ dhoma e zhveshjes (apodyterium), $B=$ dhe $C=$ Dhomë e larjes me ujë të vakët (tepidarium); $D=$ Dhomë e djersitjes, Sauna (Sudatorium) $\mathrm{E}=$ Dhomë e larjes me ujë të nxehtë (Calidarium); $\mathrm{F}=$ Vend për ngrohjen e ujit (Praefurnum) $\mathrm{G}=$ Dhomë e rritur më vonë $-\mathrm{H}=$ Kaltbaderaum (frigidarium) $=$ Dhomë e ftohtë. 
atëhershëm i ri Neritan Ceka dhe Lazar Papajani dhe ndodhet në komunën e Bradasheshit, rreth $7.4 \mathrm{~km}$ (= 5 milje romake) në veriperëndim të Elbasanit, vetëm 40 metra nga rruga romake Egnatia (Copë rruge: Peqin-Skampa (Elbasan).

Rrjedha e Fikas, e cila është pothuajse e thatë gjatë verës, mbledh ujin nga burimet nëntokësore dhe ushqen me të sot cisternat e vjetra të kompleksit.

Krahasuar me spas të tjera bashkëkohore, sipërfaqja e strukturës është mjaft modeste.

Përmbledhur mes dy masonerive pothuajse paralele, sot ende saktësisht e dukshme, sipërfaqja e përgjithshme e kompleksit të ndërtesës është 41.5 x 11 m. e madhe.

Banjat termike vetë janë të vendosura në anën perëndimore të kompleksit në një sipërfaqe prej përafërsisht $240 \mathrm{~m}^{2}$.

Hapësirat arkitektonike janë të strukturuara mirë dhe funksionojnë: një nymphaeum i madh (Nympheum) jashtë dhe brenda.

Një dhomë dollap me kyç (dhomë me shkallë), e cila furnizohet nga një kanal me ujë të ftohtë nga cisternat, që lidhet me njëri-tjetrin dhomën e ujit të ftohtë (frigidarium), dhomën e ujit të vakët (tepidarium) dhe nga dy hapësira (Schwitzraum = sudatio dhe Schweigeraum = laconicum) ekzistuese Kalidarium.

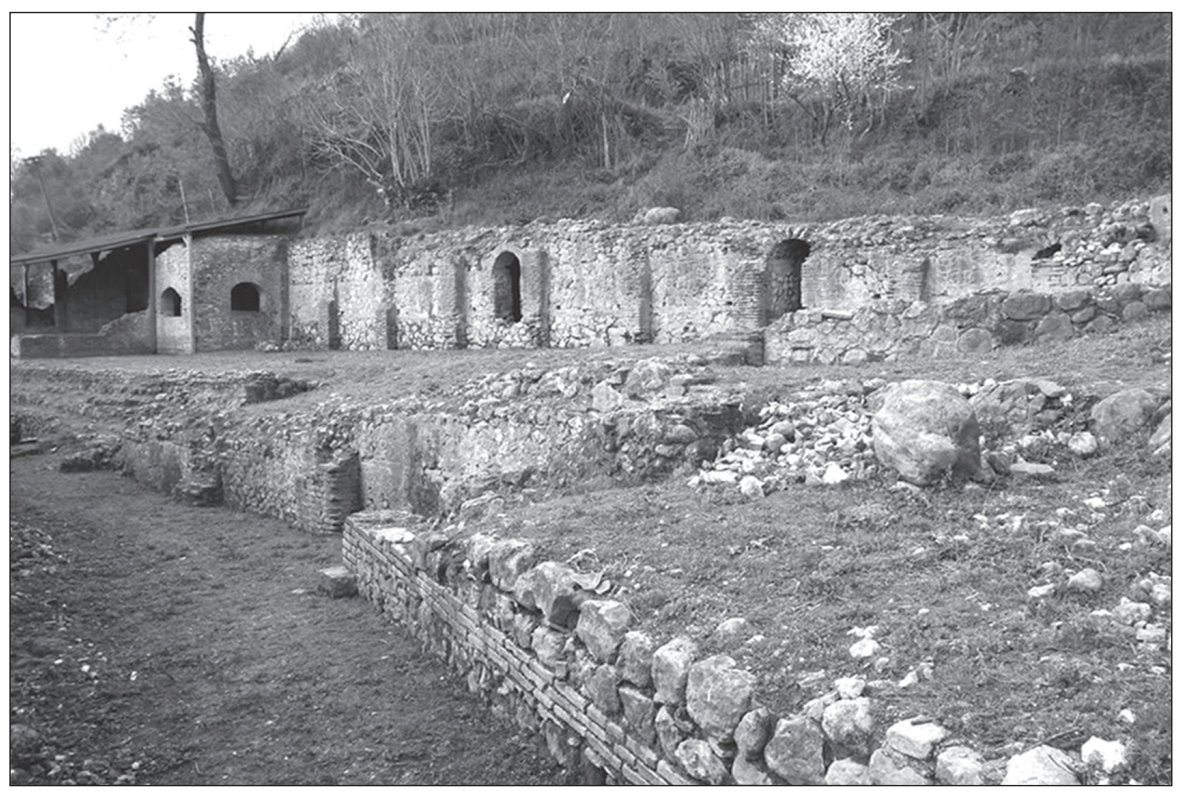

Ad Quintum, Bradashesh (Elbasan), Cisternat dhe ambientet e termave 


\section{Albanon \\ Revistë kulturore}

Në Apodyterium ju mund të shihni ende gjurmë të vogla të ngjyrave origjinale dhe motiveve me lule.

Fasada e Nympheum është 26 metra larg, gjatësi. Presioni i masës së tokës ndaj fasadës zbutet nga një mur i gjatë.

Ne shohim hapjet asimetrike të tri cisternave të mbuluara me një shtresë cilindrike me tulla, të cilat ende ushqehen me burime nëntokësore.

Sheshi përpara Nymphaeum, i cili shërbeu si një shëtitore për mysafirët e banjos termale, ishte nga një shkallë, sot ende pjesërisht e dukshme, lidhur me Via Egnatia.

Pavarësisht nga viti i vetëm në vendin e "gabuar" të dhëna bashkangjitur, është sistemi jashtëzakonisht interesant, unik termik nga kohët romake për të dashurit e kulturës së huaj dhe / ose vizitorët e interesuar, nëse jo shumë e vështirë, të paktën jo e lehtë për t'u gjetur.

Do të ishte e këshillueshme që këshilli i qytetit për këtë objetkt të jepte të dhënat përkatëse të paktën në tri vende në rrugët, Peqin-Elbasan, rruga Elbasan-Tiranë, prapa urës hekurudhore (në të dy drejtimet) dhe para hyrjes në banjë (në të dy drejtimet!).

\section{Bibliografi}

Mario de Matteis et al., Via Egnatia. Da/Von/Nga Durrësi e/und/dhe Apollonia a/nach/në Ohrid. Athena Verlag, Oberhausen, 2011: 80-83. 